\title{
Impact of minerals policy on sustainable development of mining sector - a comparative assessment of selected EU countries
}

\author{
Olga Janikowska ${ }^{1} \cdot$ Joanna Kulczycka ${ }^{2}$ \\ Received: 28 May 2020 / Accepted: 8 January 2021 / Published online: 17 February 2021 \\ (C) The Author(s) 2021
}

\begin{abstract}
Sustainable access to raw materials has been growing concern for the EU policy from 2008. Germany, Finland, United Kingdom, Portugal and Greece were the first European countries to introduce and develop own minerals policy (2010-2012). Each of Member State prioritized own targets, but sustainability, waste management and climate were also underlined. In 2015 the 17 Sustainable Development Goals were established and adopted in the EU policy framework to monitor and measure the social, economic and environmental aspects. Next Paris Agreement targets and climate neutral has been introduced. They have significant impact also on mining industry. Therefore the purpose of this paper is to discuss the relationship between mineral policy in chosen countries and achieving the Sustainable Development Goals and EU climate policy target. Due to limited data for mining sector the impact of mineral policy on sustainable mineral supply and $\mathrm{CO}_{2}$ emissions have been analyzed to identify the specific challenges, trends and successful factors of transition. It was shown that well developed mineral policy - in case of Finland - allow increase over $20 \%$ of production with over $20 \%$ decrease of $\mathrm{CO}_{2}$ emission. Moreover productivity in the sector in almost all analyzed country has been increased, what can show some correlation between mineral policy and SDG 12. However more detailed indicators for monitoring and assess the mineral policy on EU level and in individual country is needed, especially in contest of impact on sustainable development. It can help to provide acceptance of local society for new investment. It is a long term process which required not only significant financial capital, new technological solutions, but also trust and transparency in monitoring in implementing environmental and social aspects.
\end{abstract}

Keywords EU mineral policy · sustainable development goals $\cdot$ mining $\cdot$ low carbon economy $\cdot$ raw materials supply $\cdot$ resource productivity

\section{Introduction}

In November 2008 the European Commission (EC) launched the Raw Materials Initiative to set out a strategy that could secure sustainable access to raw materials, in particular to Critical Raw Materials (CRMs). The publication of the "Communication on the Raw Materials Initiative - Meeting our critical need for growth and jobs in Europe" (COM 699, 2008) and Roadmap to a Resource Efficient Europe (COM

Olga Janikowska

olgajan@min-pan.krakow.pl

1 Mineral and Energy Economy Research Institute, Polish Academy of Science, Wybickiego 7a, Cracow, Poland

2 AGH University of Science and Technology, Faculty of Management, Gramatyka 10, /10 Cracow, Poland
5712011 ) which promotes a shift towards a resource efficient and low-carbon economy to help achieve more sustainable growth were a turning point for European minerals policy. A large variety of activities have been conducted to support research and innovation (Smol and Kulczycka 2019), to exchange best practices and to improve public awareness and policy (Tilton et al. 2018). Key areas covered increased transparency (Alstin 2017), environmental and social performance (Mancini and Sala 2018), sustainability (De Sa 2019) and climate change (United Nations Environmental Programme UNEP 2020), as well as acceptance and trust of the mining industry. For example, a Strategic Implementation Plan for the European Innovation Partnership (EIP) on Raw Materials (RM) was established and the Raw Materials Information System (RMIS) was created. In the mining sector many research projects have been supported by European Union (EU) financial instruments such as Horizon 2020 (H2020) and Knowledge and Innovation Community Raw Materials (KIC 
RM) partnership bringing together businesses, research centres and universities. The goal was to increase innovation in exploration, mining and processing, recycling and the substitution of raw materials, as well as to foster international cooperation and improve the framework conditions for sustainable development and increase resource efficiency. All activities should be consistent with the EU commitment to the United Nations (UN) Sustainable Development Goals (SDGs). In 2015 all EU Member States adopted the 2030 Agenda for Sustainable Development, which is based on 17 SDGs with 5 key elements: people, planet, partnership, prosperity, peace and 169 indicators. However, knowledge about the mining sector's contribution to the SDGs is still limited (Endl et al. 2019). Moreover, in the EC reflection paper Towards a Sustainable Europe by 2030, published in 2019, it was underlined that "the most serious sustainability deficit and the greatest challenge is the ecological debt which we are running up by overusing and depleting our natural resources and thereby threatening our ability to meet the needs of future generations within the limits of our planet". The EU advised Member States to revise or develop their own minerals policy, taking into account their needs and priorities in the sector. Germany, Finland, United Kingdom, Portugal and Greece were the first European countries to introduce and develop a new mineral policy (2010-2012). They proposed sustainable access to mineral resources from primary and secondary sources and emphasized that the sustainable use of raw materials is in line with other environmental policies focusing on climate neutrality, resource efficiency and waste minimisation.

The idea of the paper is to present general trends - the impact of the implementation of the mineral policy on the contribution of the mining sector to the achievement of SDGs. In the EU Roadmap to a Resource Efficient Europe (COM 571, 2011) and most countries the aim of mineral policy were to boost domestic supply of raw materials, shift towards a resource efficient and low-carbon economy, therefore the analysis focusing on assessment data about $\mathrm{CO}_{2}$ emissions, mineral production and resource productivity in chosen EU countries in last 10 years.

\section{Methodology}

The search was first performed using widely used online scientific literature research tools and mining reports to discuss the congruence between mineral policy and the SDGs in Europe. For this purpose, the Web of Science and Scopus databases were used, with the keywords "sustainable development goals" and "mineral policy" and "Europe" focusing on the impact of mineral policy and mining sector to the achievement of SDGs in European countries. Then, five countries that were the leaders in introducing minerals policy in the EU were selected. We analyze published English version of Mineral Policy Reports of Germany, Finland, United Kingdom, Portugal and Greece and we assess the importance of sustainable development aims. For analysis English version of Mineral Policy Word Cloud method was used, being a visualization technique that is increasingly used to display the relative frequency of various keywords following a document search (Dhou et al. 2018). In the Word Cloud the font size represents the number of keywords in every analyzed mineral policy report. The next step was to identify the correlation between mineral policy and SDGs and to assess whether a mineral policy resulted in changes in environmental sector performance. Therefore based on statistical data, first changes of resource productivity and mineral production and $\mathrm{CO}_{2}$ emissions from mining sector were analyzed for individual countries in the period (20092018). The obtained results are compared with changes of $\mathrm{CO}_{2}$ emissions in analyzed countries and in energy sector to compare the trends and to identify the impact of the mining sector on implementation of SDGs in the area of climate and resource productivity.

\section{Sustainable development aims of mining sector in Europe and developing countries}

The set of SDGs is the main global reference for sustainable development policies (Mancini and Sala 2018). In the European Mineral Raw Materials report enabling SDGs, the European Association of Mining Industries, Metal Ores \& Industrial Minerals (EUROMINES) claims that the European mineral raw materials industry contributes to economic, social and environmental sustainability. According to the mining and SDGs lead document, Mapping mining to the sustainable development goals: An Atlas, the mining sector can influence all the SDGs, but there is a need to divide them into three main categories of impact: very direct, moderately direct and indirect (Fig.1).

The International Council on Mining and Metals (ICMM) has outlined 10 principles that underpin sustainable development in the mining industry and intersect with SDGs, which mainly include commitments to protect biodiversity, respect human rights and contribute to sustainable development (ICMM 2016). According to the UNEP report Mineral Resource Governance in the twenty-first Century, Gearing Extractive Industries Towards Sustainable Development, the extractive sector can influence all 17 SDGs. Extracting minerals from the Earth creates opportunities, challenges and risks to sustainable development, and what should be emphasized is the basis of sustainability. Minerals are essential for human wellbeing and are fundamental to virtually all sectors of the economy. However, mining also poses critical challenges and risks for long-term sustainability. 
Fig. 1 Mining and the 17 SDGs (UNDP 2016)

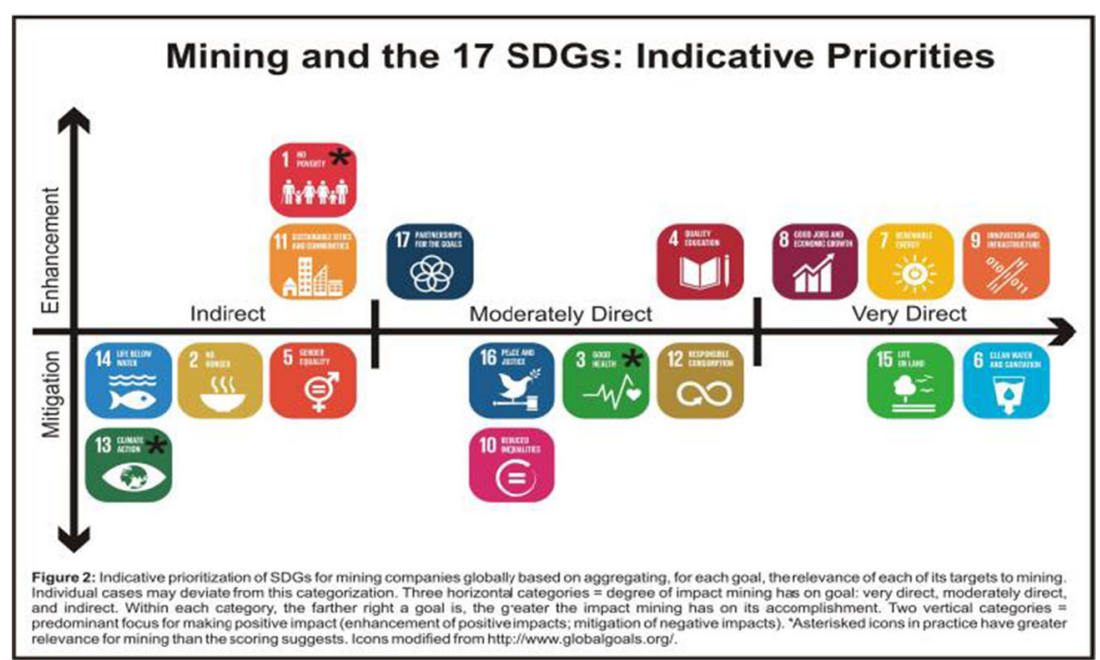

Some papers analyze the relationship between the mining activities of individual companies and the SDGs (Reis Monteiro et al. 2019), showing mainly a contribution of SDGs, for example by creating shared value or influencing the interests of the local community. They can be identified at different stages of mining life (Tajvidi et al. 2019). The impact of mining on SDGs can be both positive and negative, however sustainability of mining is a key requirement and most mining companies claim that they are at the forefront of a multifaceted approach to sustainability as their license to operate depends on their effective incorporation of social and environmental regulations, health and safety standards and values.

However, the analyses focus mainly on developing countries, as in a few low and middle income countries rich in nonfuel minerals, mining makes a significant contribution to national economic development (Ericsson and Löf 2018), while the role of the mining sector in the EU economy is much lower. According to the EU statistical office (Eurostat), in 2017 there were approximately 17,500 enterprises operating in mining and quarrying according to their main activity in the EU-27. They employed a total of 413,200 people, representing $0.3 \%$ of all employees in the non-financial business economy and generated EUR 40.0 billion of added value which accounted for $0.6 \%$ of the total non-financial business economy. The extraction of petroleum and natural gas accounted for $38.5 \%$ of the sector's turnover, another $29.9 \%$ of the turnover came from other mining and quarrying, $13.1 \%$ from the extraction of metal ores, $11.6 \%$ from the extraction of hard coal and lignite, and $9.6 \%$ from activities supporting mining in 2017. Policies related to energy and climate change are also important factor, as they set a legal regulations for mining and processing raw materials. The EU aims to become a low-carbon and energy-efficient economy in the coming decades. $\mathrm{CO}_{2}$ emissions from the entire mining and quarrying sector in EU-27 accounted for only about $1 \%$ of total $\mathrm{CO}_{2}$ emissions and dropped from 27.4 Mt in 2012 to $25.5 \mathrm{Mt}$ in 2018 (Eurostat).

\section{The role of sustainable development in mineral policies of selected EU countries}

According to the EC - the UN framework of SDGs does not include an explicit goal on raw materials, but raw materials can have an influence, directly or indirectly, on all the goals. Raw materials make a potential contribution to different SDGs along the value chain, from extraction to manufacturing, use and end of life, which are reflected in national mineral strategies.

The aim of The German Government's raw materials strategy Safeguarding a sustainable supply of non-energy mineral resources for Germany (Rohstoffstrategie der Bundes Regierung - Federal Ministry of Economics and Technology of the Federal Republic of Germany, 2010) is to shape the appropriate policies. It is underlined that social and economic progress is impossible without good governance, respect for human rights and compliance with environmental and social standards.

According to the Finland's Minerals Strategy (Suomen Mineraalistrategia - Ministry of Employment and Economy of the Republic of Finland, 2010), the country is a global leader in the sustainable use of mineral resources and the mineral sector is one of the key foundations of the Finnish national economy. The strategy assumes that Finland should take a proactive role in implementing the principles of sustainable development in the mining sector, and ensuring that extraction and processing comply with established best-practice guidelines. Moreover, new policy instruments has been proposed like for example improvement the minerals sector's financing opportunities, or using tax incentives to promote 
exploration for natural resources and for efficient use of resources.

According to the strategy, efficiently managed and sustainably utilized mineral resources secure the long-term supplies of raw materials at the national level, while creating preconditions for stable regional development far into the future. The Resource Security Action Plan: Making the most of valuable materials (Department for Business, Innovation \& Skills, and Department for Environment, Food and Rural Affairs of the UK Government, 2012) introduced in the United Kingdom, indicates that resources should be used more efficiently to ensure that materials can be re-used, remanufactured or recycled. The strategy in the area of minerals in the UK intend sustainable usage of minerals as long as possible while securing adequate supplies and making sure that the environmental impacts caused by mining processes and the transport of minerals is minimized. The Resource Security Action Plan also identifies opportunities for greater use of the sustainable extraction of critical raw materials from the UK' own indigenous resources and wider economic and environmental opportunities to develop more sustainable resource management.

The Greek National Policy for the Strategic Planning and Exploitation of Mineral Resources (Ministry of Environment, Energy and Climate Change of the Republic of Greece, 2012) acknowledges the importance of mineral raw materials (MRMs), which contribute to progress and development, ensure a high standard of living and create a competitive national and regional economy and new job positions. One of the main goals of this policy is to ensure that the supply of MRMs to society should be managed in a sustainable manner, in accordance with the national policies of sector development, environmental protection and the principles of sustainable development.
National Strategy for Geological Resources (Council of Ministers of the Republic of Portugal, 2012) launched in Portugal is focused on the mining industry and aims to promote a mining sector which is dynamic and sustainable at social, economic and territorial levels, capable of promoting the growth of the national economy and regional development, ensuring economic return and employment.

The analysis of the available English version of the minerals policy for these 5 countries with the Word Cloud visualization shows that expressions such as materials, minerals, resources, policy, supply, deposit/resource are more important than sustainability and efficiency, while climate and waste are not at all important (Fig. 2). More detailed content analysis has shown that sustainability can be the most important in these documents as it is mentioned nearly 20 times (except Portugal), and many documents focus not only on primary resources but also on waste management, and less on the climate and the circular economy (Tab. 1), which were less highlighted in the EU policy at that time.

Even the number of pages in available English version of strategies varies (United Kingdom - 56 pages, Germany - 28 pages, Finland - 20 pages, Portugal - 17 pages and Greece - 10 pages) the word sustainability was found in every document. Even, when these strategies were approved there were not yet defined 17 SDGs. Detailed text analysis show that most of them focusing on SDG 12, dedicated mainly to improving resource efficiency, and some of them to SDG 13 dedicated to climate change.

The UN's main targets of SDG 12, among other objectives, are to achieve sustainable management and an efficient use of natural resources, substantially reduce waste generation, rationalize inefficient fossil-fuel subsidies, and reflect environmental impact on reporting. As far as this aspect of SDG 12 is
Fig. 2 Word Cloud of expressions in English version of German, Finnish, UK, Portuguese and Greek minerals strategies
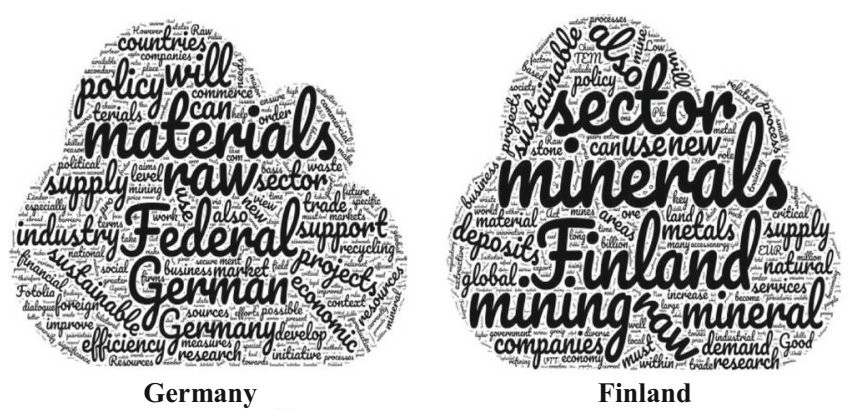

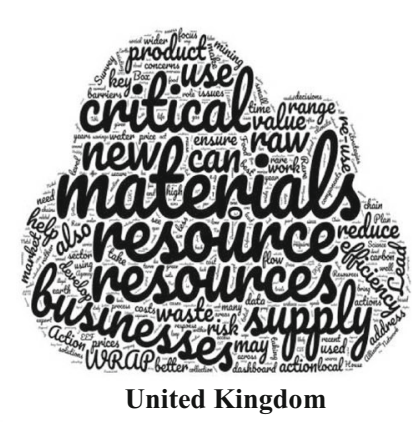

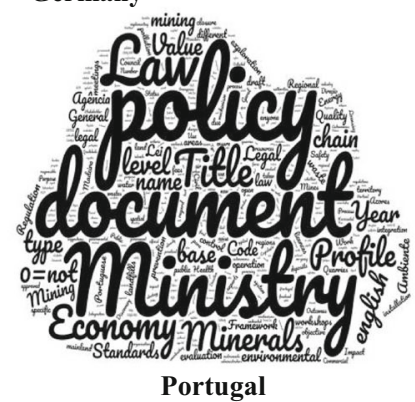

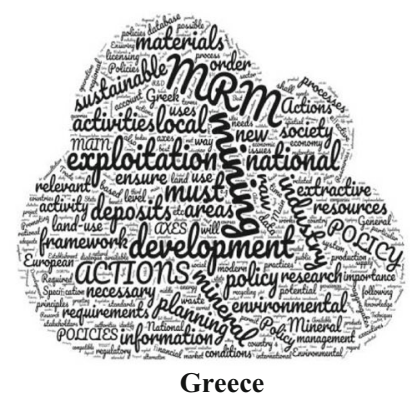


Table 1 Content analysis for chosen words in mineral strategies of the EU selected countries

\begin{tabular}{llllll}
\hline Word & Germany & Finland & United Kingdom & Portugal & Greece \\
\hline Circular economy & 0 & 0 & 4 & 0 & 0 \\
Waste & 19 & 8 & 50 & 22 & 7 \\
Sustainability & 30 & 28 & 22 & 2 & 15 \\
Cycle & 7 & 6 & 17 & 0 & 4 \\
Climate & 5 & 2 & 10 & 0 & 4 \\
Green & 1 & 2 & 23 & 0 & 1 \\
Carbon footprint & 0 & 0 & 0 & 0 & 0 \\
Secondary & 8 & 1 & 9 & 0 & 1 \\
\hline
\end{tabular}

concerned, resources productivity, which refers to quantity and quality service and can be articulated in monetary terms as the monetary yield per unit resource, is important. According to Humphreys (2020), factors which shape changes in productivity in mining are: innovation and technological change, resource depletion and ore quality, government regulations, investment lags, economies of scale, capacity utilization, strikes, accidents and other unplanned production stoppages, other factors. Therefore the assessment of productivity versus volume of production has been done for each analyzed country in the period 2009-2018 to identify potential changes after mineral policy introduction.

The main targets of SDG 13 are to strengthen resilience and adaptive capacity to climate, though, among other factors, integrating climate change measures into national policies, strategies and planning, and promoting mechanisms for raising capacity for effective climate change-related planning and management. SDG 13 has been included in most of EU policy as in 2014 EU leaders agreed on a target to cut greenhouse-gas (GHG) emission in the EU by at least $40 \%$ below 1990 levels by 2030. It has been enhanced in the European Green Deal (2019), where the EC proposed to increase this target to at least $55 \%$ in a responsible way to move towards a climateneutral economy by 2050 . The pace of changes varies, however all countries that have minerals policy in place experienced significant reduction in minerals production and $\mathrm{CO}_{2}$ emissions and increased resource productivity. Though the analyzed countries are significant producers of raw materials in Europe, the share of $\mathrm{CO}_{2}$ emissions from the mining and quarrying sector is only $0.5 \%-1 \%$ of total $\mathrm{CO}_{2}$ emissions. In the case of the energy sector, in 2009-2018 it ranged from $25 \%$ to $66 \%$. As climate aspects are important of SDG and were mentioned in most of minerals policies, therefore the trends of $\mathrm{CO}_{2}$ emission from mining and energy sector for each analyzed country were conducted.

\section{Germany}

Analysis of statistical data of mining sector in Germany in 2009-2018 indicates a significant increase in total productivity from 1.9 euro to 2.3 euro per $\mathrm{kg}$ (Fig. 3), with reduction in $\mathrm{CO}_{2}$ emissions of about $50 \%$ from 2011 , and a moderate decrease in mining production from 230 to 220 Mton (Fig. 4). Germany is one of the countries in the world that has set the goal of climate neutrality by or before 2050 in its national law, focusing mainly on reduction of GHG emissions in energy, buildings, transport, industry, and agriculture (UBA Climate
Fig. 3 Mineral production (Mtons) versus resource productivity (euro/kg) in Germany based on EUROSTAT and CEIC data

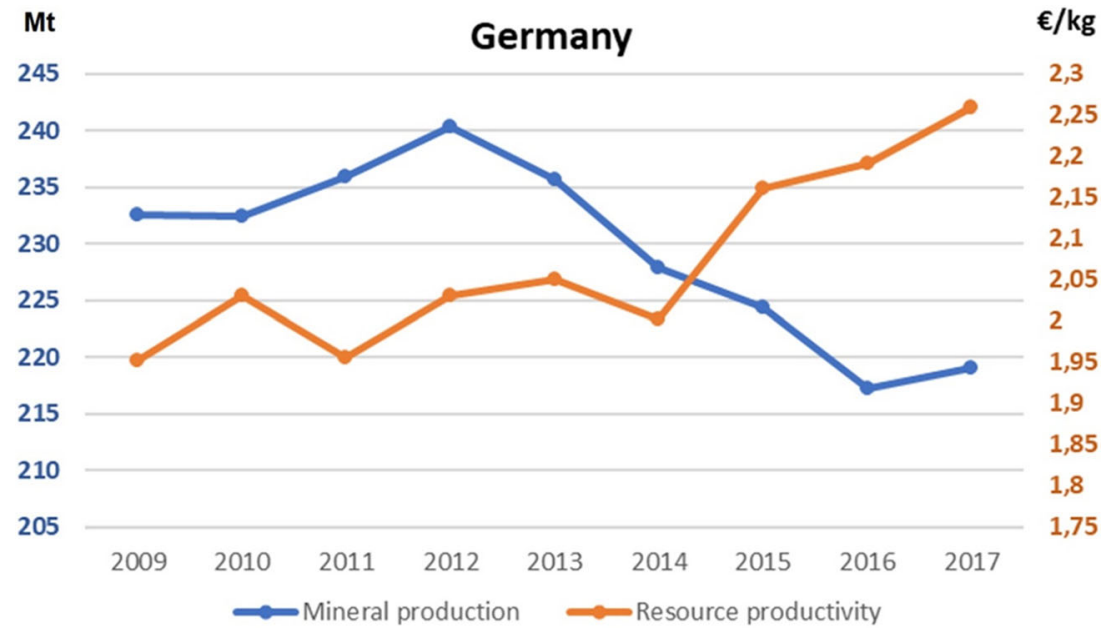


Fig. $4 \mathrm{CO}_{2}$ emissions from the following sectors: mining and quarrying, and electricity, gas, steam and air conditioning supply versus total in Germany $\left(\mathrm{CO}_{2}\right.$ ktons) based on EURTOSTAT data

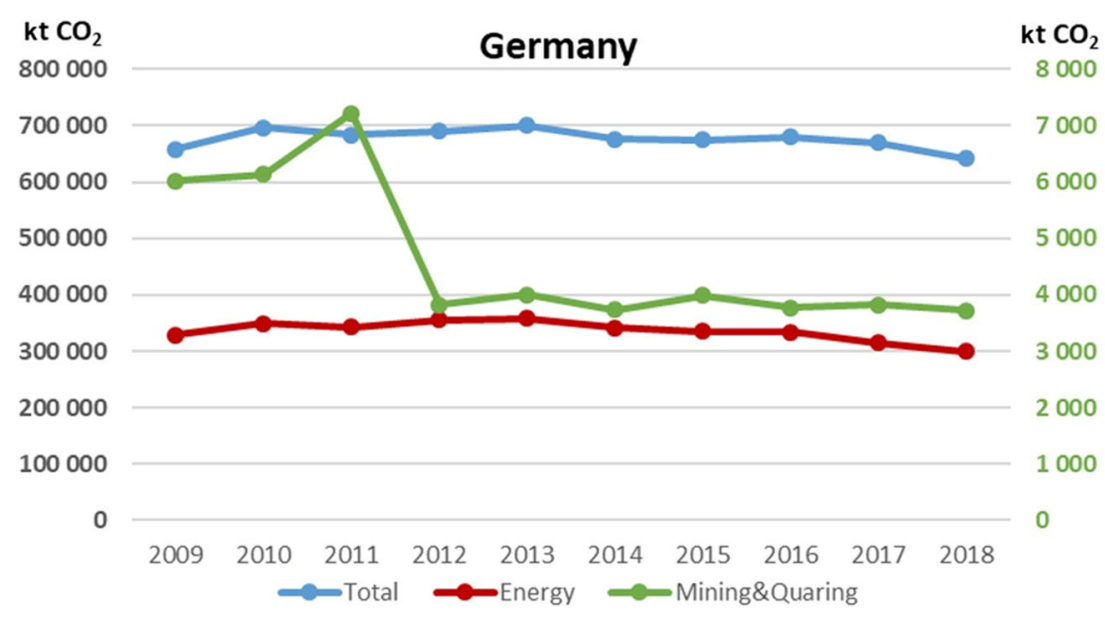

Action Law 2020). Since the beginning of the 1990s, Germany has been reducing GHG emissions. However, since the announcement in 2011 of the final resignation from nuclear energy and fossil fuel and acceleration of the expansion of renewable energy sources (RES) as part of the energy transformation strategy (German Energiewende), we have had this trend reversed - in 2011. The emission lowered mainly in electricity sales (in households and in sales and services). Therefore, German experts write about the monitoring transformation paradox - an increase in the share of renewable energy in the energy support package $\mathrm{CO}_{2}$ emissions.

\section{Finland}

The Finland's Mineral Strategy assumes both a reduction in waste and the conservation of resources, while promoting sustainable utilization and recycling of raw materials. According to the Government Report on the Medium-term Climate Change Plan for 2030 - Towards Climate-Smart Day-to-Day Living from 2017, the target for Finland for the shared effort to reduce emissions in the sector by 2030 is $39 \%$ compared to 2005 . The analysis of mineral production shows a significant increase in the volume of mining production (Fig. 5), a decrease in $\mathrm{CO}_{2}$ emissions in 2012-2016, and an increase in 2016-2018 (Fig. 6), while maintaining resource productivity at the level of about 1.1 euro/kg. GHG emissions in Finland tend to show quite a large annual fluctuations, mainly due to the hydrological situation in the Nordic countries. However, the energy sector is the most significant source of GHG emissions in Finland with an 74\% share of the total emissions in 2017, being 41.1 Mtons $\mathrm{CO}_{2 \mathrm{e}}$. Emissions have decreased by $23 \%\left(12.5 \mathrm{Mt} \mathrm{CO}_{2 \mathrm{e}}\right.$.) since 1990 and by $5 \%$ (2.3 $\mathrm{Mt} \mathrm{CO}_{2 \mathrm{e}}$ ) since 2016 (Reporting on Policies and Measures under Article 13 and on Projections under Article 14 of Regulation (EU) No 525/2013).

\section{United Kingdom}

The Resource Security Action Plan underlines resource efficiency as the most important issue. Moreover, the UK has an ambitious plan to reduce all GHG emissions to net zero by 2050 , compared with the previous targets of at least an $80 \%$ reduction from 1990 levels (https://greengb.campaign.gov.uk/). Data
Fig. 5 Mineral production (Mtons) versus resource productivity (euro/kg) in Finland based on EUROSTAT and CEIC data

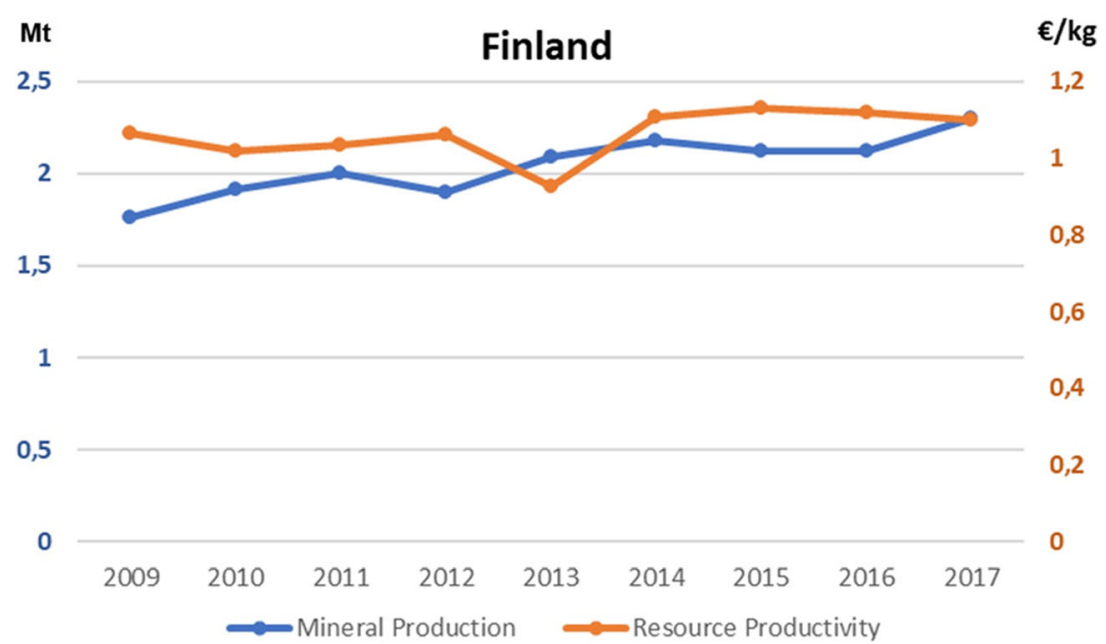


Fig. $6 \mathrm{CO}_{2}$ emissions from the following sectors: mining and quarrying, and electricity, gas, steam and air conditioning supply versus total in Finland $\left(\mathrm{CO}_{2}\right.$ ktons) based on EUROSTAT data

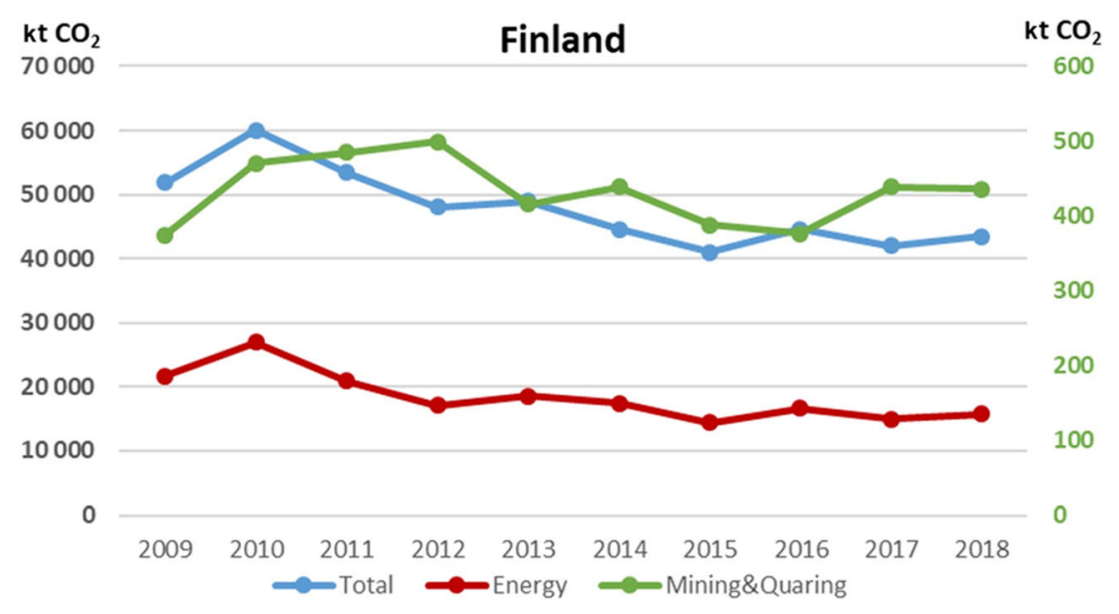

analysis shows that the UK initially reduced production of minerals and has been maintaining this figure at around $100 \mathrm{Mt}$ over the last few years and a stable increasing trend in resource productivity from 3.1 euro/kg to 3.8 euro/kg (Fig. 7). UK was also able to reduce $\mathrm{CO}_{2}$ emissions by $13 \%$, but not in the mining sector (Fig. 8). The United Kingdom shows starting from the 2013 implementation of the principle of decoupling, i.e. separation of mineral production from resource productivity. Dynamics is unequivocal. While $\mathrm{CO}_{2}$ emissions fell by $34.2 \%$. in general, this is a result of technological progress, economic structural change and enforcement of environmental regulations such as the Climate Change Act from 2008 (The decoupling of economic growth from carbon emissions: UK evidence).

\section{Portugal}

The National Strategy for Geological Resources in Portugal launched in 2012 is mainly focused on mining, but it also underlines opportunities for resource efficiency and the full use of mineral resources (National Strategy for Geological Resources. Council of Ministers of the Republic of Portugal). Portugal has a target of reducing GHG between $18 \%$ and $23 \%$ by 2020 , and between $30 \%$ and $40 \%$ by 2030 (http://tda-mobility.org/tdamember-portugal/). According to analyzed data, Portugal has managed to reduce $\mathrm{CO}_{2}$ emissions by almost $35 \%$, but the volume of mineral production has reduced significantly from 1 . $4 \mathrm{Mt}$ to $0.6 \mathrm{Mt}$. Portugal is one of the countries potentially the most affected by climate change. In Portugal most sectors of the economy can highlight significant gains in energy and resource use efficiency. An analysis of GHG emissions per unit of Gross Domestic Product (GDP) shows that a decoupling trend between GDP and emissions started in 2005, resulting from decarbonization of the economy, that is, an economy with less carbon emitted for each unit of produced wealth that is being maintained (Roadmap for Carbon Neutrality 2050 (RNC2050) Long-Term Strategy For Carbon Neutrality of The Portuguese Economy by 2050).

\section{Greece}

In the Greek National Policy for the Strategic Planning and Exploitation of Mineral Resources announced in 2012,
Fig. 7 Mineral production (Mtons) versus resource productivity (euro/kg) in UK based on EUROSTAT and CEIC data

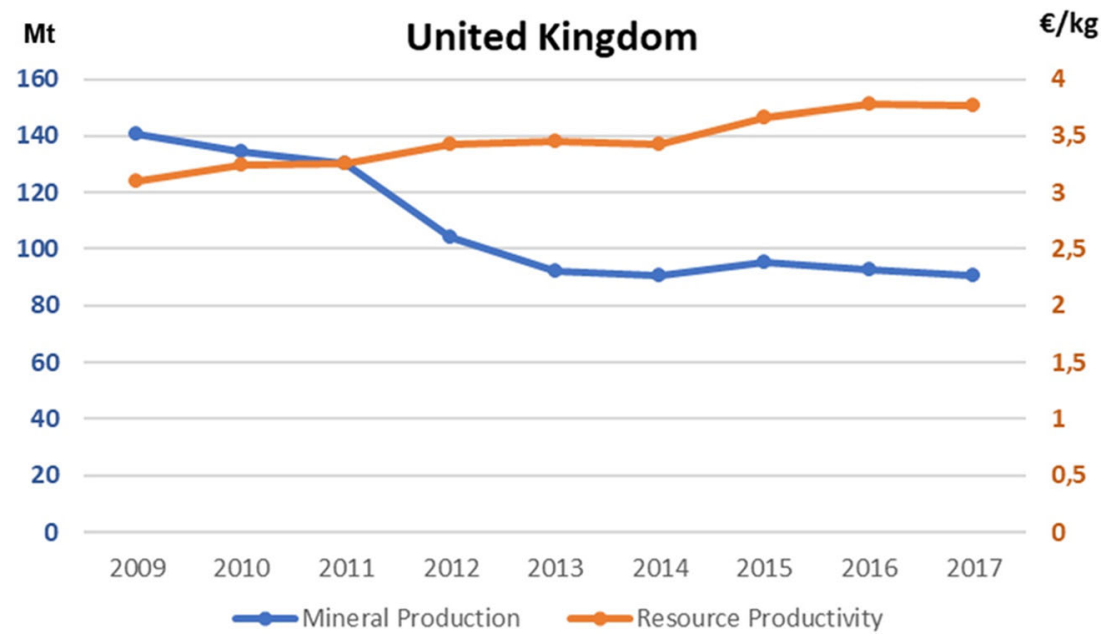


Fig. $8 \mathrm{CO}_{2}$ emissions from the following sectors: mining and quarrying, and electricity, gas, steam and air conditioning supply versus total in the $\mathrm{UK}\left(\mathrm{CO}_{2}\right.$ ktons) based on EUROSTAT data

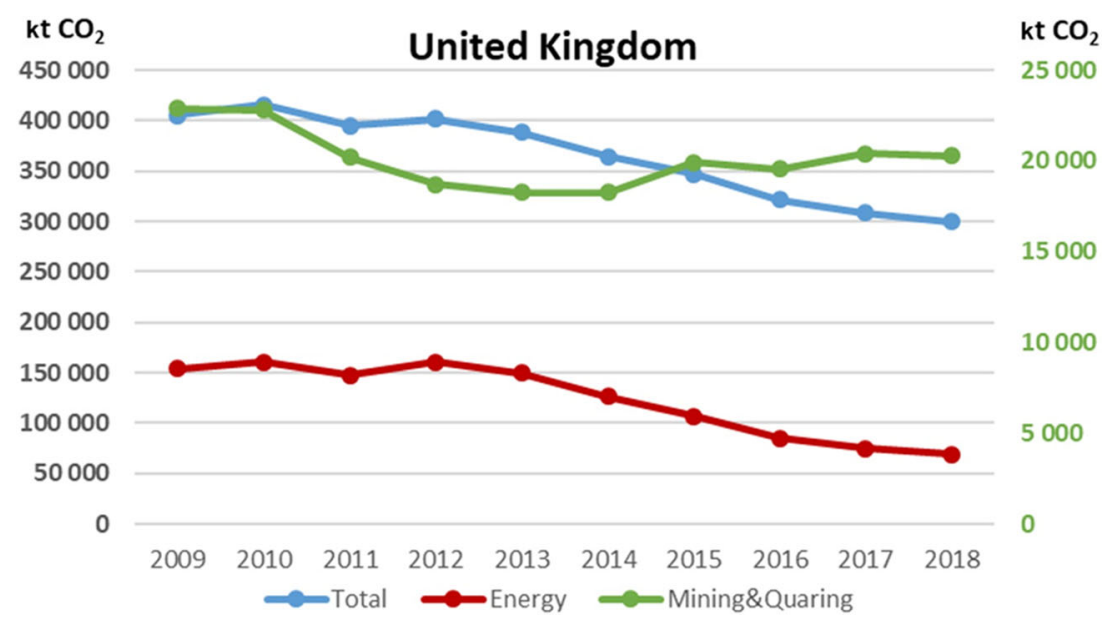

kt $\mathrm{CO}_{2}$ 5000 production must be carried out in conformity with the principles of sustainable development, economic growth, as a social pillar and according to environmental requirements (National Policy for the Strategic Planning and Exploitation of Mineral Resources. Ministry of Environment, Energy and Climate Change of the Republic of Greece, 2012). The long-term economic crisis in Greece was the reason of decreased the national GDP per capita. At the same time energy consumption and $\mathrm{CO}_{2}$ emission was reduced.

It should be emphasized is that Greece's 2030 target for GHG emissions was not covered by the EU Emissions Trading System (non-ETS), and amounted to $14 \%$ compared to 2005, as set out in the Effort Sharing Regulation (ESR) (Greece, Summary of the Commission assessment of the draft National Energy and Climate Plan 2021-2030). Mineral production has been reduced by $36 \%$, while resource productivity increased from 1.2 euro $/ \mathrm{kg}$ to almost 1.6 euro $/ \mathrm{kg}$ (Fig. 9a,b), with a decrease in the $\mathrm{CO}_{2}$ production of the mining industry (Fig. 10a,b).

\section{Conclusions}

Strategy with the aim to secure sustainable access to raw materials, in particular to Critical Raw Materials (CRMs) and the publication of the "Communication on the Raw Materials Initiative - Meeting our critical need for growth and jobs in Europe", in 2008, enhanced many Member States to revise or develop their own mineral strategies, still it took a few years to developed and another few years before the actions taken had its results. Germany, Finland, United Kingdom, Portugal and Greece were the first European countries that introduced and developed a new minerals policy (2010-2012). The analysis with the Word Cloud visualization of English version of analyzed documents shows that expressions such as mineral, critical, resources, supply, policy, actions, law were more important than sustainability, efficiency, and climate. Nevertheless, all the policies indicated the importance of mining sector in the national economy and implementation of the principles of sustainable development. Sustainable access to mineral resources has been proposed and the sustainable use of raw materials being in line with other environmental policies focusing on climate neutrality, which corresponded with
Fig. 9 Mineral production (Mtons) versus resource productivity (euro/kg) in Portugal based on EUROSTAT and CEIC data. $\mathrm{CO}_{2}$ emissions from the following sectors: mining and quarrying, and electricity, gas, steam and air conditioning supply versus total in the ( $\mathrm{CO}_{2}$ ktons) based on EUROSTAT data

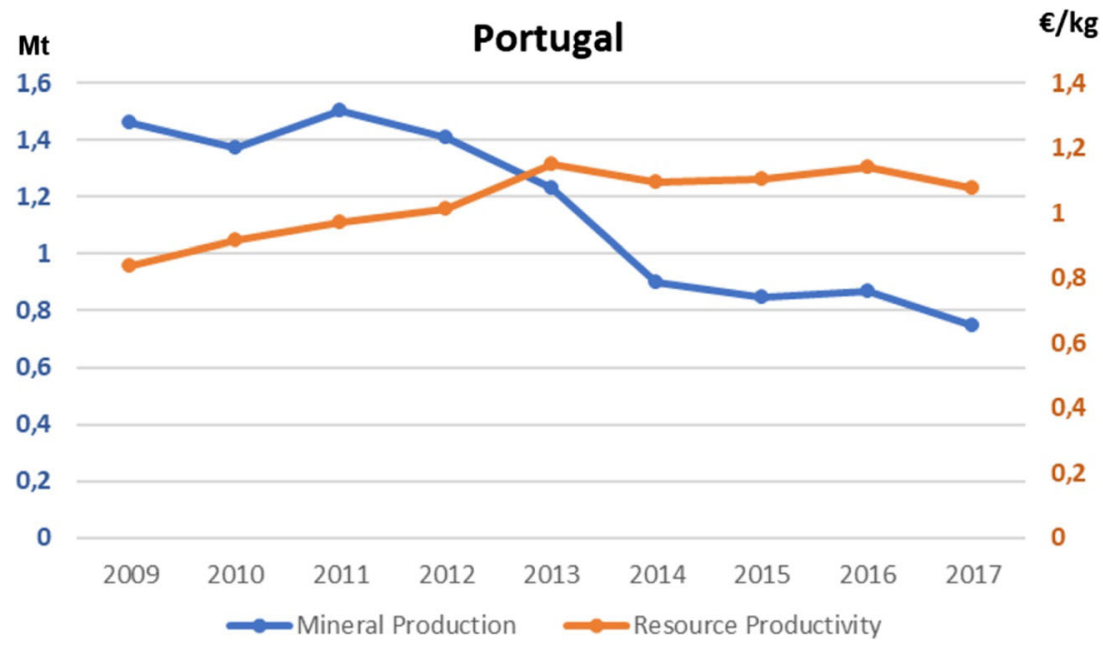


Fig. 10 Mineral production (Mtons) versus resource productivity (euro/kg) in Greece based on EUROSTAT and CEIC data $\mathrm{CO}_{2}$ emissions from the following sectors: mining and quarrying, and electricity, gas, steam and air conditioning supply versus total in the $\left(\mathrm{CO}_{2}\right.$ ktons) based on EUROSTAT data

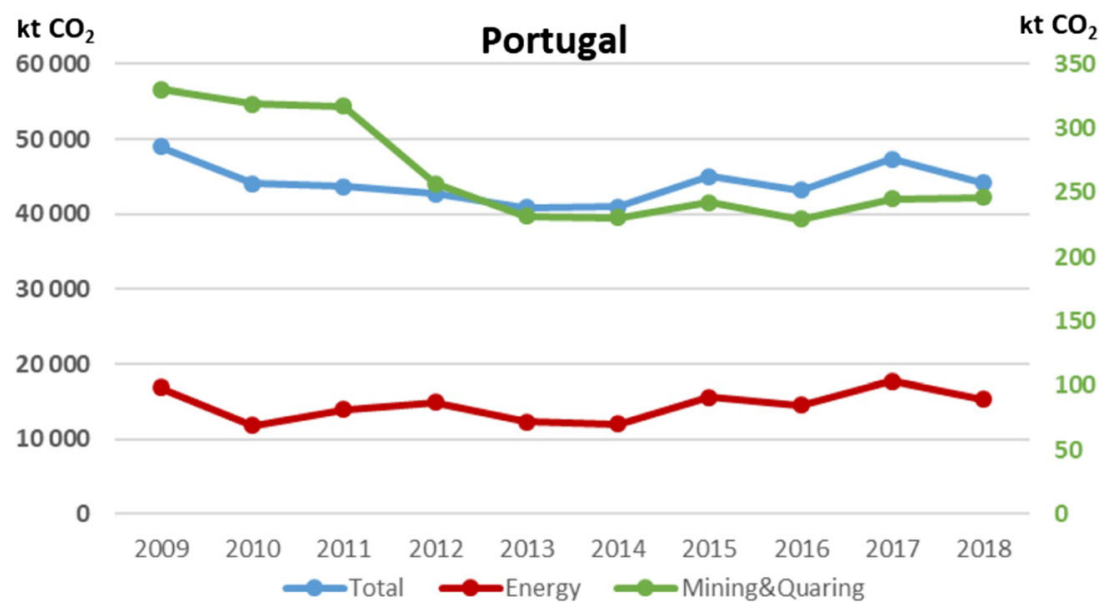

adopted in 2015 SDG 12 and SDG 13. Even in most mineral policy access to raw materials was underlined significant drop in minerals production has been recorded (except for Finland), with increase resource productivity. As a result it was reduction of $\mathrm{CO}_{2}$ emissions, but the tendency was much slower. A summary of changes in 2009 and 2018 for every country was presented in Table 2.

The success of Finland's sustainable and minerals nexus could be seen in a more detailed mining policy plan compared to other EU members i.e. by focusing on the policy for whole sector, for systematic activities in each mining phase from creating own R\&D programme to development of an action plan called Making Finland a leader in the sustainable extractive industry - action plan, proposing indicators for a monitoring system and the development of long-term objectives.

For the future sustainable development of mining in the EU, it is crucial to minimize environmental the negative aspects of the mining industry. In most EU countries, the implementation of the SDGs, increased use of IT tools and support for process innovation from many projects and programs (H2020, KIC Raw Materials, etc.) do not provide sufficient incentives for new mining investments and increased volume of mining activity. The lack of investment results mainly from the long-term investment process, low social acceptance of mining, poor

Table 2 Summary of results for $\mathrm{CO}_{2}$ emissions, mineral production, resource productivity (between 2009 and 2018, 2009 is a reference point)

\begin{tabular}{llll}
\hline Country & $\begin{array}{c}\% \mathrm{CO}_{\mathbf{2}} \\
\text { emissions }\end{array}$ & $\begin{array}{l}\text { \% mineral } \\
\text { production }\end{array}$ & $\begin{array}{l}\text { \% resource } \\
\text { productivity }\end{array}$ \\
\hline Germany & $1.8 \% \uparrow$ & $6.2 \% \downarrow$ & $15.7 \% \uparrow$ \\
Finland & $19.1 \% \downarrow$ & $23.2 \% \uparrow$ & $3.2 \% \uparrow$ \\
United & $23.8 \% \downarrow$ & $55.6 \% \downarrow$ & $21.8 \% \uparrow$ \\
$\quad$ Kingdom & & & $28.8 \% \uparrow$ \\
Portugal & $3.3 \% \downarrow$ & $94.8 \% \downarrow$ & $28.8 \% \uparrow$ \\
Greece & $25.1 \% \downarrow$ & $54.2 \% \downarrow$ & \\
\hline
\end{tabular}

geological conditions, stricter environmental regulation compared to other countries, etc. In addition, as the number of new renewable energy facilities (solar, wind) increased to meet the Paris Agreement targets and to be climate neutral by 2050, more minerals were imported, either in pure or semi-finished form. Demand for main metals is likely to continue to grow in the twenty-first century. An analysis of the increased requirements associated with the transition to a low-carbon economy shows that it could lead to the next mining and metals boom and increasing demand for metals up to tenfold by 2050 (Hodgkinson and Smith 2018). Some analysts claim that the substitution and recovery of raw materials from extractive waste and recycling might not be sufficient to meet the increased demand in the near future as it will take time before products reach the end of their life cycle and can be reused.

Open Access This article is licensed under a Creative Commons Attribution 4.0 International License, which permits use, sharing, adaptation, distribution and reproduction in any medium or format, as long as you give appropriate credit to the original author(s) and the source, provide a link to the Creative Commons licence, and indicate if changes were made. The images or other third party material in this article are included in the article's Creative Commons licence, unless indicated otherwise in a credit line to the material. If material is not included in the article's Creative Commons licence and your intended use is not permitted by statutory regulation or exceeds the permitted use, you will need to obtain permission directly from the copyright holder. To view a copy of this licence, visit http://creativecommons.org/licenses/by/4.0/.

\section{References}

Agora (2014) The German Energiewende and its Climate Paradox. An Analysis of Power Sector Trends for Renewables, Coal, Gas, Nuclear Power and $\mathrm{CO}_{2}$ Emissions, 2010-2030 https://staticagoraenergiewendede/fileadmin2/Projekte/2014/Energiewende-Paradox/ Analysis_Energiewende_Paradox_web_ENpdf Accessed (1 September 2020)

Dhou K, Hadzikadic M, Faust M (2018) Typeface size and weight and word location influence on relative size judgments in tag clouds. 
Journal of Visual Languages \& Computing Volume 44:97-105. https://doi.org/10.1016/j.jvlc.2017.11.009

EC (2008) Communication from the Commission to the European Parliament and the Council - The raw materials initiative: meeting our critical needs for growth and jobs in Europe (COM 699)

EC (2011) Communication from the Commission to the European Parliament, the Council, the European Economic and Social Committee and the Committee of the Regions: Roadmap to a Resource Efficient Europe. (COM 571)

EC (2019) Communication from the Commission to the European Parliament, the Council, the European Economic and Social Committee and the Committee of the Regions: The European Green Deal. (COM 640 final)

EC (2019) Towards a Sustainable Europe by 2030. https://ec.europa.eu/ commission/sites/beta-political/files/rp sustainable europe 30-01 en_web.pdf.

Endl A, Tost M, Hitch M, Moser P, Feiel S (2019) Europe's mining innovation trends and their contribution to the sustainable development goals: Blind spots and strong points. Resources Policy 101440: 101440. https://doi.org/10.1016/j.resourpol.2019.101440

Ericsson M, Löf O (2019) Mining's contribution to national economies between 1996 and 2016. Miner Econ 32:223-250. https://doi.org/ 10.1007/s13563-019-00191-6

Euromines (2019) European Mineral Raw Materials enabling SDGs. http://wwweurominesorg/news/the-european-mineral-rawmaterials-industry-enabling-sdgs Accessed (15 September 2020)

Fraser J (2019) Creating shared value as a business strategy for mining to advance the United Nations Sustainable Development Goals. The Extractive Industries and Society 6(3):788-791. https://doi.org/10. 1016/j.exis.2019.05.011

Heffron RJ, Downes L, Ramirez Rodriguez OM, McCauley D (2018) The emergence of the "social license to operate" in the extractive industries? Resources Policy.:101272. https://doi.org/10.1016/j. resourpol.2018.09.012

Hodgkinson JH, Smith MH (2018) Climate change and sustainability as drivers for the next mining and metals boom: The need for climatesmart mining and recycling. Resources Policy:101205. https://doi. org/10.1016/j.resourpol.2018.05.016

Humphreys D (2020) Mining productivity and the fourth industrial revolution. Miner Econ 33:115-125. https://doi.org/10.1007/s13563019-00172-9
Jin Y (2017) Development of Word Cloud Generator Software Based on Python. Procedia Engineering 174:788-792. https://doi.org/10. 1016/j.proeng.2017.01.223

Mancini L, Sala S (2018) Social impact assessment in the mining sector: Review and comparison of indicators frameworks. Resources Policy 57:98-111. https://doi.org/10.1016/j.resourpol.2018.02.002

Reis Monteiro NB, Aparecida da Silva E, Moita Neto JM (2019) Sustainable Development Goals in Mining. J Clean Prod 228:509520. https://doi.org/10.1016/j.jclepro.2019.04.332

De Sa P (2019) Mining and sustainable development: territorializing the mining industry. Miner Econ 32:131-143. https://doi.org/10.1007/ s13563-018-0149-8

Smol M, Kulczycka J (2019) Towards innovations development in the European raw material sector by evolution of the knowledge triangle. Resources Policy 62:453-462. https://doi.org/10.1016/j. resourpol.2019.04.006

Tajvidi Asr E, Kakaie R, Ataei M, Mohammadi MRT (2019) A review of studies on sustainable development in mining life cycle. J Clean Prod 229:213-231. https://doi.org/10.1016/j.jclepro.2019.05.029

Tilton JE, Crowson PCF, DeYoung JH Jr, Eggert RG, Ericssone M, Guzmán JI, Humphreys D, Lagos G, Maxwell P, Radetzki M, Singer DA, Wellmer FW (2018) Public policy and future mineral supplies. Resources Policy 57:55-60. https://doi.org/10.1016/j. resourpol.2018.01.006

UBA (2020) Climate Action Law. https://wwwumweltbundesamtde/en/ indicator-greenhouse-gas-emissions Accessed (10 October 2020)

Umweltbundesamt (2020) Treibhausgas-Emissionen in Deutschland. http://www.umweltbundesamt.de/daten/klimawandel/treibhausgasemissionen-in-deutschland Accessed (8 October 2020)

UNDP (2016) Mapping Mining to the SDGs: An Atlas. https:// wwwundporg/content/undp/en/home/librarypage/povertyreduction/mapping-mining-to-the-sdgs\%2D\%2Dan-atlashtml Accessed (3 September 2020)

UNEP (2020) Mineral Resource Governance in the 21st Century. Development, Gearing Extractive Industries Towards Sustainable. isbn:978-92-807-3779-0

Umweltbundesamt (2020) Treibhausgas-Emissionen in Deutschland. http://wwwumweltbundesamtde/daten/klimawandel/treibhausgasemissionen-in-deutschland Accessed (20 October 2020)

Publisher's note Springer Nature remains neutral with regard to jurisdictional claims in published maps and institutional affiliations. 